\title{
Evaluation of in vitro antioxidant activity of saponin-rich fraction from leaves of Zanthoxylum zanthoxyloides
}

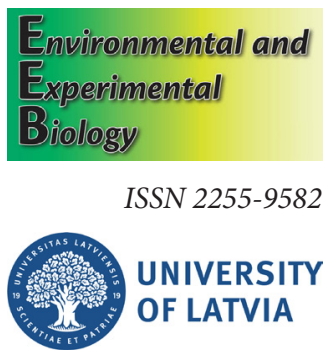

\author{
A.O. Olusola ${ }^{1 *}$, A.O. Elekan ${ }^{1}$, A.O. Olusola ${ }^{1}$, T.O. Ogidan' ${ }^{1}$, O.E. Ekun ${ }^{1}$, \\ I.O. Onoagbe ${ }^{2}$
} ${ }^{1}$ Department of Biochemistry, Adekunle Ajasin University, Akungba Akoko, Ondo State, Nigeria
${ }^{2}$ Department of Biochemistry, Faculty of Life Science, University of Benin, Benin City, Edo State,
Nigeria

${ }^{\star}$ Corresponding author, E-mail: augustine.olusola@aaua.edu.ng

\begin{abstract}
Zanthoxylum zanthoxyloides, also known as Fagara zanthozyloides, is a medicinally important plant of the Rutaceae family. It contains high concentration of saponins and has several medicinal uses. The aim of this study was to evaluate in vitro antioxidant properties of saponin-rich extract from leaves of Z. zanthoxyloides. Phytochemical screening of crude methanol extract of leaves of $Z$. zanthoxyloides revealed presence of saponins, alkaloids, flavonoids and tannins. Extraction of saponins from methanolic extract was performed by a standard procedure. The resulting saponin-rich fraction was investigated for in vitro antioxidant activity with free radicals, superoxide anion radical, hydrogen peroxide and ferric ions. The extract exhibited potent and concentration-dependent increase in free radical scavenging activity against free radicals. Scavenging capacity of superoxide radicals and hydrogen peroxide scavenging of the extract also raised with increased extract concentration. The apparent antioxidant activity of the saponin-rich fraction of leaf extract from $Z$. zanthoxyloides suggests its potential use in prevention and treatment of diseases.
\end{abstract}

Key words: antioxidative capacity, free radical scavenging activity, saponins, Zanthoxylum zanthoxyloides. Abbreviations: DPPH, 1,1-diphenyl-2-picrylhydrazyl.

\section{Introduction}

Medicinal plants contain chemical substances that can be used for therapeutic purposes, and some of them are used as precursors for synthesis of pharmaceuticals (Sofowora 1984). Plants produce a variety of non-essential chemicals as a part of biotic defense, but numerous studies have demonstrated that many phytochemicals can protect against human diseases (Kumar et al. 2009). Historically, plants have played a significant role in health protection (Vogel 1997). Phytochemical screening has unveiled the chemicals responsible for these functions (Faraz et al. 2003), but structural analysis has provided the basis for their therapeutic potencies (Stintzing et al. 2002). This has also increased the relevance of wild plants in drug development.

One such plant considered of great importance is Zanthoxylum zanthoxyloides. Z. zanthoxyloides (Rutaceae), commonly called 'toothache bark' or'candle wood' in English or 'Orin ata' in Yoruba, is widespread in the West Tropical Africa where it occurs in savanna and dry forests, as well as in the coastal area of Nigeria, mostly in the southern part of the country (Iwu et al. 1999). Z. zanthoxyloides contains various secondary metabolites, which have diverse biological activties, including antioxidative, antiinflammatory, antisickling, antibacterial, antiviral, antihepatotoxicity, antiallergic, antitumoral and antihypertensive properties (Sofowora et al. 1975; Andersson et al. 1996; Adesina 2005). The methanol extract prepared from powdered root of $Z$. zanthoxyloides has been reported to contain flavonoids, chelerythrine, berberine and phenol canthine-6-one and possesses strong antibacterial activity (Odebiyi, Sofowora 1979; Tsuchiya et al, 1996). These extracts have been used as components of antiseptic, antiparasitic and analgesic preparations for managing smallpox, syphilis and related disease conditions (Olatunji 1983).

Saponins are natural glycosides of steroid or triterpene nature, which have been shown to exhibit a variety of biological and pharmacological properties, including antioxidant, hypolipidemic potential and inhibition of erythropoesis in Rattus novergicus (Elekofehinti et al. 2012). However, to the best of our knowledge, there is no information available on in vitro antioxidant properties of saponins from leaves of $Z$. zanthoxyloides. Therefore, this study was carried out to evaluate the in vitro antioxidant potential of saponins from $Z$. zanthoxyloides leaves. 


\section{Materials and methods}

\section{Collection and identification of plant material}

Fresh Z. zanthoxyloides leaves were collected in farmland towards the end of the harmattan season from Ugbe Akoko in the Akoko North-East Local Government Area of Ondo State, Nigeria. Plants were identified and certified at the herbarium of Plant Science and Biotechnology Department, Adekunle Ajasin University, Akungba Akoko. The leaves were washed with clean water, air-dried until a constant weight was obtained, and pulverized by an electric blender into powder. The powdered plant material was kept in an airtight container and preserved in a cool, dark and dry place until the extraction.

\section{Preparation of extract}

A sample $(100 \mathrm{~g})$ of the powdered leaf was soaked in 500 $\mathrm{mL}$ of methanol (95\%) for $72 \mathrm{~h}$, with occasional stirring using a glass rod to ensure proper mixture of the vessel content. The content was then filtered through two layers of cheesecloth. The extract (filtrate) was then concentrated under reduced pressure at $45^{\circ} \mathrm{C}$ until the extraction solvent was completely removed. A green soluble crude residue was obtained.

\section{Qualitative phytochemical analysis}

Chemical tests for the screening and identification of bioactive chemical constituents were carried out on the extract using standard procedures (Trease, Evans 1989; Sofowora 1993; Harborne 1998) with minor modifications.

\section{Isolation of saponins from crude methanolic extract}

Isolation of the saponin-rich fraction was carried out using a procedure described by Abdel-Gawad et al. (1999) and Elekofehinti et al. (2013) with slight modification. The crude extract was partitioned with hexane and water (1:2, $\mathrm{v} / \mathrm{v})$. After thorough shaking, the mixture was allowed to stand overnight and the water layer was concentrated and partitioned between ethyl acetate and $n$-butanol $(1: 3, v / v)$. The butanol fraction was concentrated to obtain the crude saponin fraction.

\section{Determination of 1,1-diphenyl-2-picrylhydrazyl radical scavenging activity}

The free radical scavenging activity of saponin-rich fraction was measured with the stable radical 1,1-diphenyl-2picrylhydrazyl (DPPH) as described by Braca et al. (2001) with slight modification. Aliquots $(1 \mathrm{~mL})$ of the extract at different concentration ( 0.2 to $0.8 \mathrm{mg} \mathrm{mL}^{-1}$ ) were added to $1 \mathrm{~mL} 0.1 \mathrm{mM}$ DPPH dissolved in $95 \%$ ethanol. The mixture was shaken vigorously and incubated in the dark at room temperature for $30 \mathrm{~min}$. The absorbance was read at $517 \mathrm{~nm}$ by a UV/Vis spectrophotometer. Ascorbic acid at the same concentration was used as a positive control. Ethanol (95\%) was used as a blank. The control solution consisted of $0.1 \mathrm{~mL}$ of $95 \%$ ethanol and $2.9 \mathrm{~mL}$ of $\mathrm{DPPH}$ solution. Analyses were carried out in triplicate. Percentage inhibition of DPPH radical was calculated as:

$$
\begin{aligned}
\text { DPPH inhibition }(\%)= & \left(A b s_{\text {control }}-A b s_{\text {sample }}\right) / A b s_{\text {control }} \\
& \times 100,
\end{aligned}
$$

where $A b s_{\text {control }}$ is the absorbance of the blank control and $A b s_{\text {sample }}$ is the absorbance of the test sample.

The $\mathrm{EC}_{50}$ (the microgram of the extract to scavenge $50 \%$ of the radicals) value was estimated from a percentage inhibition plot using a non-linear regression plot. A lower $\mathrm{EC}_{50}$ value indicates larger antioxidant activity.

\section{Determination of hydrogen peroxide scavenging activity}

The ability of the saponin-rich extract to scavenge hydrogen peroxide was determined according to the method of Ruch et al. (1989) as described by Keser et al. (2012) with slight modification. A solution of hydrogen peroxide $(4 \mathrm{mM})$ was prepared in $0.2 \mathrm{M}$ phosphate buffer $(\mathrm{pH}$ 7.4). The extract at varying concentration of $\left(0.2\right.$ to $\left.0.8 \mathrm{mg} \mathrm{mL}^{-1}\right)$ in distilled water was added to $600 \mu \mathrm{L}$ of $4 \mathrm{mM}$ hydrogen peroxide solution. The absorbance of test samples was read at $230 \mathrm{~nm}$ after 10 min against a blank solution containing phosphate buffer without hydrogen peroxide. The absorbance of hydrogen peroxide was taken as the control. Ascorbic acid was used as a standard antioxidant. The percentage of hydrogen peroxide scavenging effect was calculated by comparing the absorbance values of the control and test samples using:

$\mathrm{H}_{2} \mathrm{O}_{2}$ scavenging capacity $(\%)=(A C-A S) / A C \times 100$, where $A C$ is the absorbance of the control and $A S$ is the absorbance of the test sample.

$\mathrm{EC}_{50}$ values were estimated from a \% inhibition versus concentration plot using a non-linear regression plot. All analyses were performed in triplicate

\section{Determination of superoxide anion radical scavenging activity}

The method described by Xie et al. (2008) was used to determine superoxide anion radical scavenging activity. Samples (1 $\mathrm{mg} \mathrm{mL}^{-1}$ final concentration) were each dissolved in $50 \mathrm{mM}$ Tris-base buffer, $\mathrm{pH} 8.3$, containing 1 mM EDTA and $80 \mu \mathrm{L}$ was transferred into a clear bottom microplate well; $80 \mu \mathrm{L}$ of buffer was added to the blank well. This was followed by the addition of $40 \mu \mathrm{L} 1.5 \mathrm{mM}$ pyrogallol (dissolved in $10 \mathrm{mM} \mathrm{HCl}$ ) into each well in the dark and the change in the rate of reaction was measured immediately at room temperature over a period of $4 \mathrm{~min}$ using a spectrophotometer at wavelength $420 \mathrm{~nm}$. The superoxide scavenging activity was calculated using the following equation:

Superoxide scavenging activity $(\%)=\left(\Delta A_{b}-\Delta A_{s}\right) / \Delta A_{b} \times$ 100 ,

where $\Delta A_{b}$ and $\Delta A_{s}$ are changes in absorption per min of blank and sample, respectively. Analyses were carried out in triplicate. 
Determination of ferric reducing antioxidant property

The reducing power of the extract was measured according to the method of Oyaizu (1986) with slight modification. An $1 \mathrm{~mL}$ aliquot of different concentration (0.2 to 0.8 $\mathrm{mg} \mathrm{mL} \mathrm{m}^{-1}$ ) of the saponin extract (0.2 M PBS, pH 6.6) was mixed with $1 \mathrm{~mL}$ of $1 \%$ potassium ferric cyanide solution. The mixture was incubated at $50{ }^{\circ} \mathrm{C}$ for $30 \mathrm{~min}$ followed by the addition of $1 \mathrm{~mL} 10 \%(\mathrm{w} / \mathrm{v})$ trichloroacetic acid. Aliquots of the incubated mixture $(1 \mathrm{~mL})$ were added to $1 \mathrm{~mL}$ of distilled water and $0.2 \mathrm{~mL}$ of $0.1 \%(\mathrm{w} / \mathrm{v})$ ferric chloride in test tubes. After a $10 \mathrm{~min}$ reaction time, the absorbance of the resulting solution was read at $700 \mathrm{~nm}$. Higher absorbance suggested stronger reducing power. Ascorbic acid was used as the reference antioxidant. An aqueous solution of known $\mathrm{Fe}$ (II) concentrations $\left(\mathrm{FeSO}_{4}\right.$ $7 \mathrm{H}_{2} \mathrm{O} ; 0.063$ to $2.0 \mathrm{mM}$ ) was used for calibration. Results were expressed as $\mathrm{mM} \mathrm{Fe}^{2+} \mathrm{mg}^{-1}$ extract.

The $\mathrm{EC}_{50}$ of extracts was calculated from a graph of absorbance at $700 \mathrm{~nm}$ versus extract concentration. All the tests were performed in triplicate.

\section{Statistical analysis}

All analyses were carried out in triplicate and data were expressed as mean \pm standard error of mean. The data were statistically analyzed using the Student's $t$-test and differences were considered statistically significant at $p<0.05$ using GraphPad Prism version 7.0 (GraphPad Software, San Diego, CA, USA).

\section{Results}

The DPPH radical scavenging activity of ascorbate (control) and the saponin-rich fraction of $Z$. zanthoxyloides leaves, at a concentration range of 0.2 to $0.8 \mathrm{mg} \mathrm{mL}^{-1}$ (Fig. 1). The standard antioxidant (ascorbate) as well as the saponinrich extract showed concentration-dependent increase in DPPH scavenging activity.

Fig. 2 shows the $\mathrm{EC}_{50}$ values of the extract for scavenging DPPH radical, as compared to ascorbate (control). Saponin-rich extract scavenged the radical to a 50\% extent at a significantly $(p<0.05)$ higher concentration when compared to ascorbate.

Evidence of the ability of the saponin-rich fraction from leaves of $Z$. zanthoxyloides to scavenge hydrogen peroxide is presented in Fig. 3, in comparison with ascorbate as a standard. Saponins had significantly $(p<$ 0.05) lower $\mathrm{H}_{2} \mathrm{O}_{2}$ scavenging capacity when compared with that of ascorbate. Also, both the ascorbate and saponin-rich fractions were capable of scavenging hydrogen peroxide in a concentration-dependent manner. The $\mathrm{EC}_{50}$ for ascorbic acid was $25.95 \times 10^{-2} \mathrm{mg} \mathrm{mL}^{-1}$ as compared with $\mathrm{EC}_{50}$ of $88.60 \times 10^{-2} \mathrm{mg} \mathrm{mL}^{-1}$ for the saponin fraction (Fig. 4).

Superoxide radical scavenging activity of ascorbate and the saponin-rich fraction from leaves of $Z$. zanthoxyloides is presented in Fig. 5. The saponin-rich fraction had lower scavenging activity at a concentration range of 0.5 to $2.0 \mathrm{mg}$ $\mathrm{mL}^{-1}$, when compared to ascorbate.

Fig. 6 shows $\mathrm{EC}_{50}$ values of the saponin fraction in scavenging superoxide anion radical, as compared to ascorbate. Saponins scavenged the radical to a $50 \%$ inhibition at a concentration of $4.53 \times 10^{-2} \mathrm{mg} \mathrm{mL}^{-1}$, while ascorbate had $50 \%$ scavenging activity at concentration of $2.23 \times 10^{-2} \mathrm{mg} \mathrm{mL}^{-1}$. The saponin fraction had a significantly $(p<0.05)$ lower $\mathrm{EC}_{50}$ value than for ascorbate.

The results for ferric reducing activity of the saponin-rich fraction, compared to the ascorbic acid standard, are shown in Fig. 7. The saponin-rich fraction had significantly $(p<$ 0.05 ) lower antioxidant activity at different concentrations when compared to ascorbate. At all concentrations used,

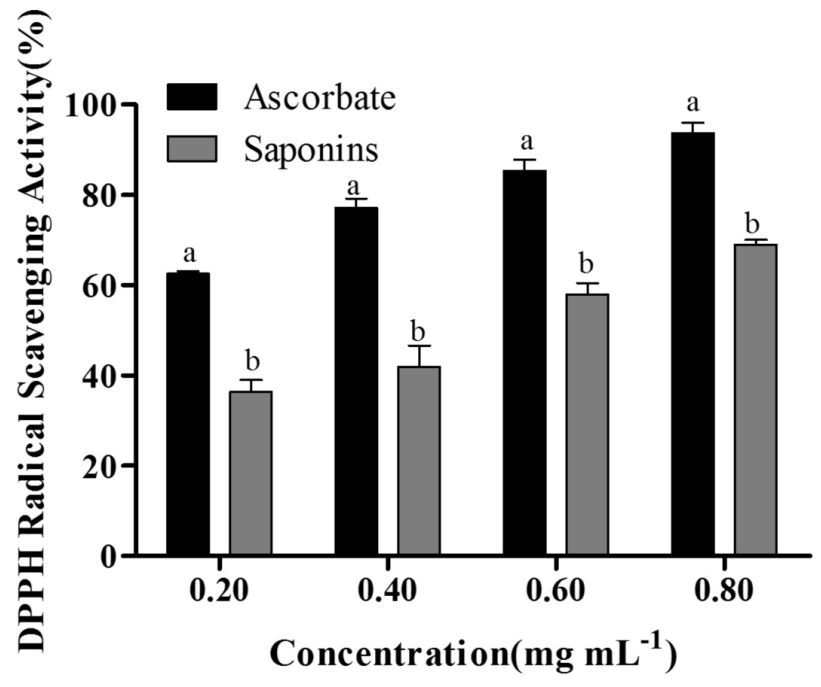

Fig. 1. DPPH radical scavenging activity of the saponin-rich fraction of leaves from $Z$. zanthoxyloides. Bars represent the mean \pm standard error $(n=3)$. Comparisons between samples were made at the same concentration. Bars with the same letters do not differ significantly $(p<0.05)$.

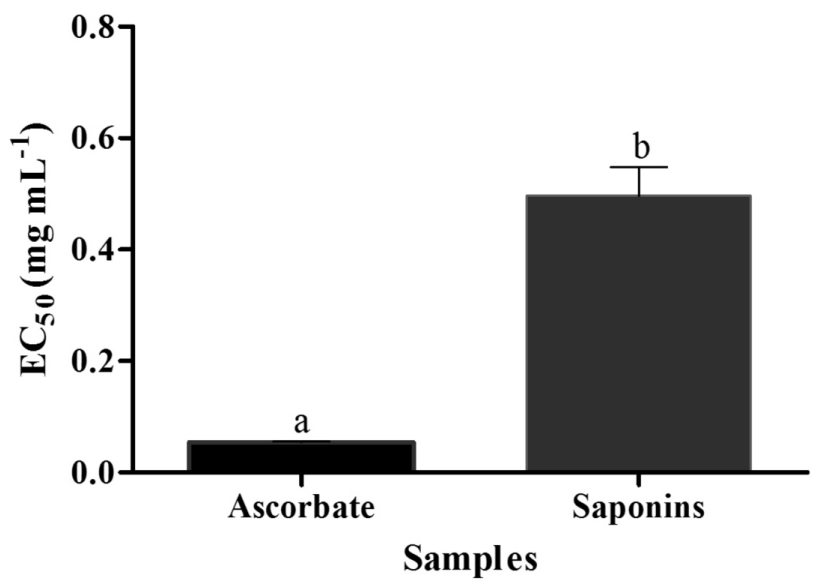

Fig. 2. $\mathrm{EC}_{50}$ values of saponin-rich fraction ofZ. zanthoxyloides leaf in scavenging DPPH radical. Bars represent the mean \pm standard error $(n=3)$. Bars with the same letters do not differ significantly $(p<0.05)$. 


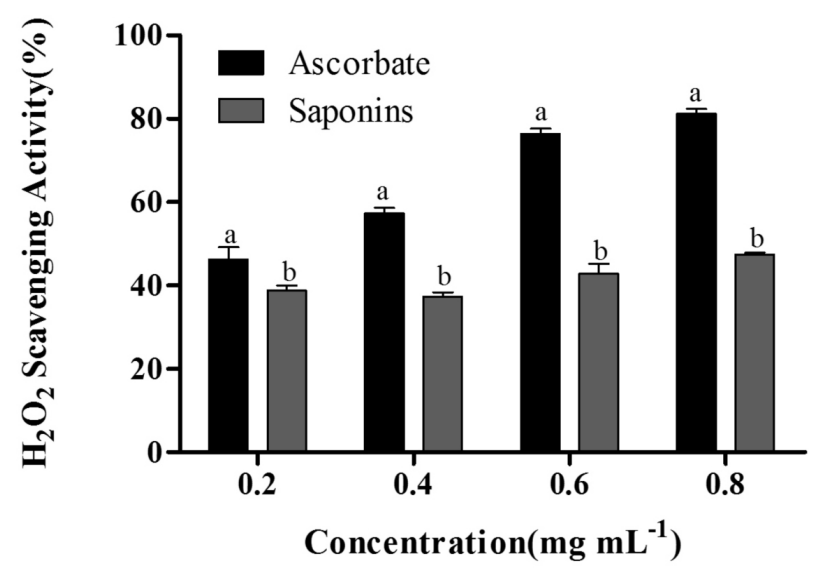

Fig. 3. Hydrogen peroxide scavenging activity of saponin-rich fraction from leaves of $Z$. zanthoxyloides. Bars represent the mean \pm standard error $(n=3)$. Comparisons between samples were made at the same concentration. Bars with the same letters do not differ significantly $(p<0.05)$.

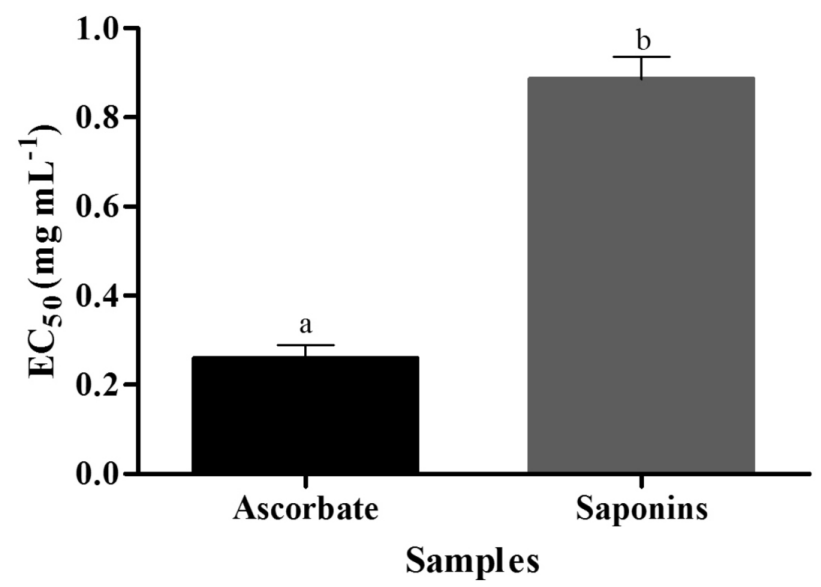

Fig. 4. $\mathrm{EC}_{50}$ values of saponin-rich fraction from leaves of $Z$. zanthoxyloides in scavenging hydrogen peroxide. Bars represent the mean \pm standard error $(n=3)$. Bars with the same letters do not differ significantly $(\mathrm{p}<0.05)$.

except $0.80 \mathrm{mg} \mathrm{mL}^{-1}$, there was no significant difference in the activity of the saponin fraction.

\section{Discussion}

The therapeutic benefits of medicinal plants are often attributed to their antioxidant potencies (Vinay et al. 2010). Natural antioxidants found in plants and vegetables have been extensively studied for their ability to protect the organism and cells from the deleterious effects induced by oxidative stress (Kamdem et al. 2012; Elekofehinti et al. 2013; Filho et al, 2014). It is well known that the antioxidant activity of chemical compounds or plant extracts vary according to the model system used. Consequently, the use of only one assay system for the determination of antioxidant activity is not advisable (Tan, Lim 2015). In the present study, the antioxidant potential of saponin-rich

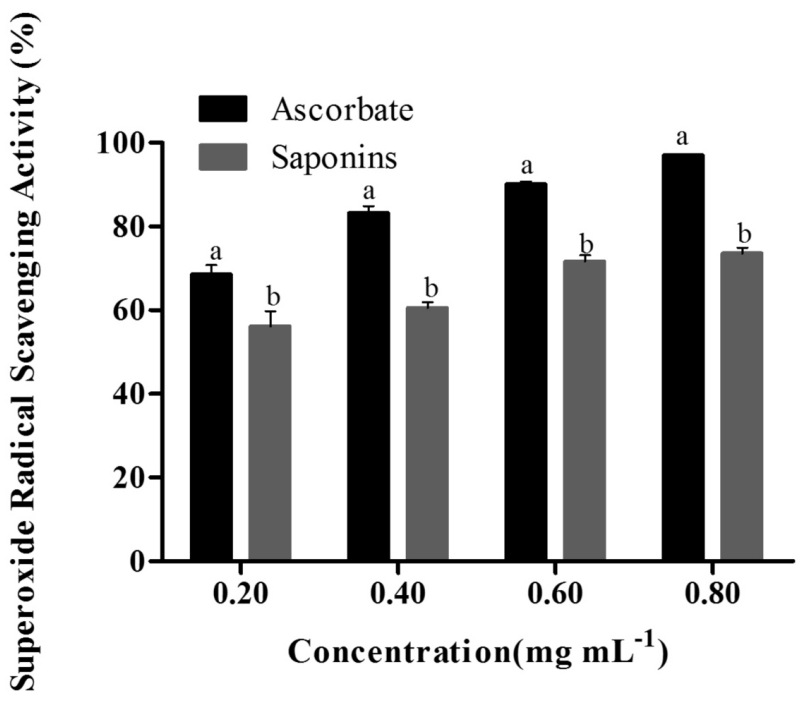

Fig. 5. Superoxide radical scavenging activities of saponin-rich fraction from leaves of $Z$. zanthoxyloides. Bars represent the mean \pm standard error $(n=3)$. Comparisons between samples were made at the same concentration. Bars with the same letters do not differ significantly $(p<0.05)$.

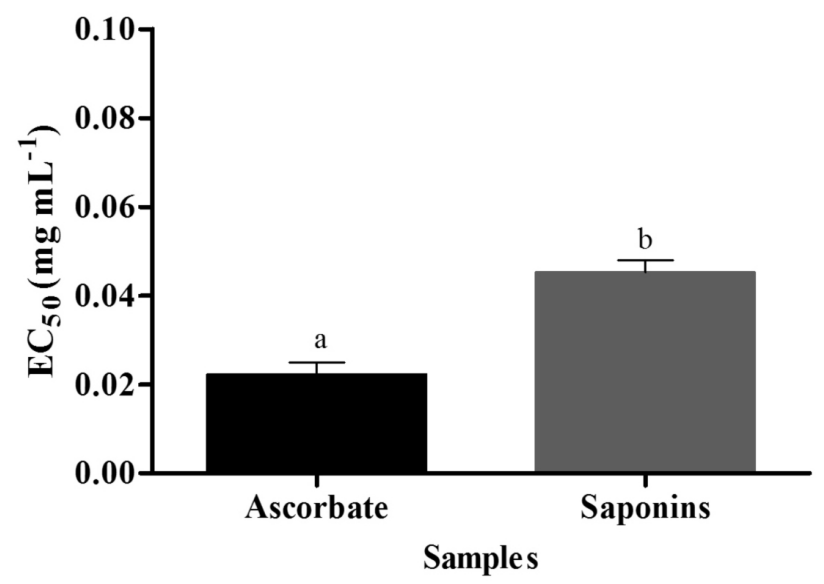

Fig. 6. $\mathrm{EC}_{50}$ values of saponin-rich fraction from leaves of $Z$. zanthoxyloides in scavenging superoxide radical. Bars represent the mean \pm standard error $(n=3)$. Bars with the same letters do not differ significantly $(p<0.05)$.

fraction from leaves of $Z$. zanthoxyloides was determined by $\mathrm{DPPH}$ radical scavenging activity, superoxide anion radical scavenging activity, hydrogen peroxide scavenging activity and ferric reducing power activity assay. Together all these assays provided a better estimation of antioxidant properties and the obtained results revealed that antioxidant activity of saponin-rich fraction of Z. zanthoxyloides was concentration-dependent.

It is well accepted that the scavenging of $\mathrm{DPPH}$ free radical by antioxidants is due to the ability of the latter to donate hydrogen (Chen, Ho 1995). The results of the free radical scavenging activity of the saponin-rich fraction as well as its $\mathrm{EC}_{50}$, in comparison to those of ascorbate (standard antioxidant) revealed that saponin-rich fraction 


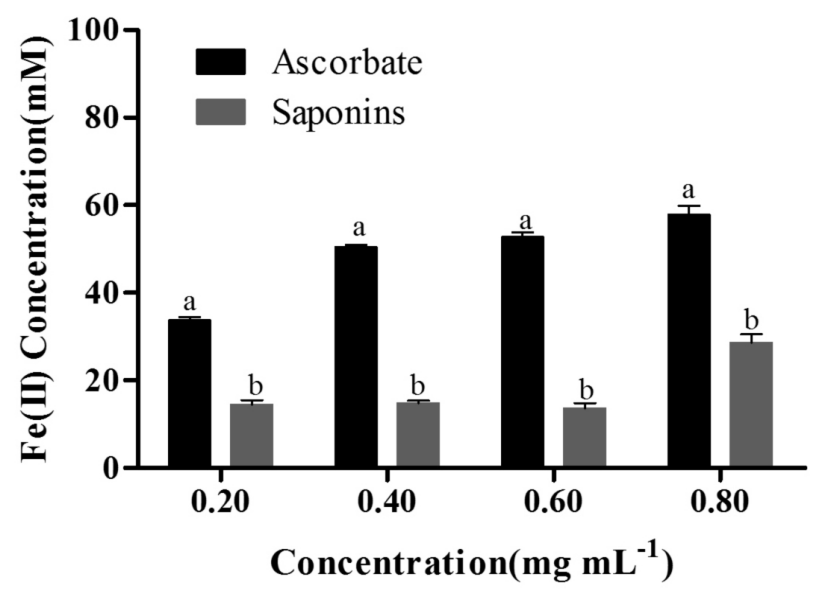

Fig. 7. Ferric reducing antioxidant properties of saponin-rich fraction from leaves of $Z$. zanthoxyloides. Bars represent the mean \pm standard error $(n=3)$. Comparisons between samples were made at the same concentration. Bars with the same letters do not differ significantly $(p<0.05)$.

showed concentration-dependent scavenging of DPPH radical. This may be attributed to its hydrogen and/or electron donating ability, which might prevent reactive radical species from reaching functionally important molecules such as lipoproteins, polyunsaturated fatty acids, DNA, amino acids, and proteins (Halliwell et al. 1992).

These results agree with earlier reports that the scavenging effect on the DPPH radical increased sharply with increasing concentration of the samples and standards (Motalleb et al. 2005, Adekunle et al. 2012). The $\mathrm{EC}_{50}$ for ascorbate and the fraction of $Z$. zanthoxyloides indicated lower scavenging capacity of saponins. Although the DPPH radical scavenging ability of the saponin-rich fraction was less than that of ascorbate, it is important that the fraction had proton-donating ability and could serve as free radical inhibitor or scavenger, acting possibly as a primary antioxidant.

Hydrogen peroxide itself is not extremely reactive, but it can be toxic to cell because it may induce formation of hydroxyl radicals in cells (Halliwell 1991). Thus, the removal of $\mathrm{H}_{2} \mathrm{O}_{2}$ is very important for antioxidant defense in cell or food systems. Results presented in Fig. 5 show that the saponin-rich fraction of $Z$. zanthoxyloides exhibited significantly lower scavenging activity when compared to that of ascorbic acid, but was able to scavenge hydrogen peroxide and inhibit the formation of hydroxyl radical to some degree. The $\mathrm{EC}_{50}$ value of the extract was larger than that of ascorbic acid, but the scavenging capacity of the extract increased with increasing concentration.

The superoxide radical is known to be very harmful to cellular components because of high reactivity and since it can initiate free radical chain reactions (Haliwell 1991). Therefore, investigation of the free radical scavenging activity is of great importance (Kanatt et al. 2007). Z. zanthoxyloides leaf extract in the present study showed good ability to scavenge superoxide anions. The $\mathrm{EC}_{50}$ values of the leaf extract were higher than those of ascorbic acid, a standard antioxidant. This indicated lower scavenging capacity of the saponin-rich fraction. Similar to these results, saponins isolated from Radix trichosanthis had efficient scavenging ability for the superoxide anion radical (Chen et al. 2014).

Reducing power assay is often used to evaluate the ability of a natural antioxidant to donate an electron or hydrogen (Yildirim et al. 2000). Reducing power of a bioactive compound is associated with its antioxidant activity and may serve as a significant reflection of its potential activity (Oktay et al. 2003). Compounds with reducing power indicate that they are electron donors and can reduce the oxidized intermediates of lipid peroxidation processes, reacting with free radicals to stabilize and block radical chain reactions (Chanda, Dave 2009). In this assay, the yellow color of the test solution changes to various shades of green and blue, depending on the reducing power of the sample. The results obtained here showed an increase in absorbance with an increase in concentration, indicating that the saponin-rich extract had effective reducing power when compared to the standard ascorbate.

The saponin-rich fraction generally exhibited low ferric reducing properties, and this agrees with previous studies (Malika et al., (2015). The low ferric-reducing property of the extract, when compared with that of ascorbate, may be attributed to the structure of their aglycones and the number of attached sugar residues (Ryu et al. 2012). In a study on antioxidant activity of saponins from Vietnamese ginseng, protective action against free radical-induced tissue injury was found (Huong et al. 1998).

Free radicals induce oxidative stress in vivo, which may lead to oxidative modification or damage of some biological structures such as lipids, proteins, and DNA, and may give rise to degenerative diseases (Muleya 2013). An exogenous supply of antioxidants can be chosen as therapy or as a preventive measure against damaging effects of reactive oxygen species (Muleya 2013). Natural sources of antioxidants are much safer to use due to less toxicity and side effects (Akharaiyi 2011). In this respect, the results of the present study in vitro look encouraging, as the extract of Z. zanthoxyloides had some pronounced radical scavenging effects.

\section{References}

Abdel-Gawad M.M., El-Sayed M.M., Abdel-Hameed E.S. 1999. Molluscicidal steroidal saponins and lipid content of Agave decipiens. Fitoterapia 70: 371-381.

Adekunle A.S., Kamdem J., Rocha, J.B. 2012. Antioxidant activity and HPLC analysis of Zanthoxylum zanthoxyloides. Rep. Opin. 4: 6-13.

Adesina S.K. 2005. The Nigerian Zanthoxylum: chemical and biological values. Afr. J. Trad. Compl. Altern. Med. 2: 282-381.

Akharaiyi F.C. 2011. Antibacterial, phytochemical and antioxidant 
activities of Datura metel. Int. J. Pharm. Technol. Res. 3: 478483.

Andersson C.M., Hallberg A., Högberg T. 1996. Advances in the development of pharmaceutical antioxidants. Adv. Drug Res. 28: 65180 .

Braca A., Tommasi N.D., Bari L.D., Cosimo P., Politi M., Morelli I. 2001. Antioxidant principles from Bauhinia terapotensis. J. Nat. Prod. 64: 892-895.

Chanda S., Dave R. 2009. In vitro models for antioxidant activity evaluation and some medicinal plants possessing antioxidant properties: an overview. Afr. J. Microbiol. Res. 3: 981-996.

Chen C.W., Ho C.T. 1995. Antioxidant properties of polyphenols extracted from green and black tea. J. Food Lipids 2: 35-46.

Chen Y., Miao Y., Huang L., Li J., Sun H., Zhao Y., Jang Y., Zhou W. 2014. Antioxidant activities of saponins extracted from Radix trichosanthis: An in vivo and in vitro evaluation. BMC Compl. Altern. Med. 14: 86-93.

Elekofehinti O.O., Adanlawo I. G., Saliu J.A., Sodehinde S.A. 2012. Saponins from Solanum anguivi fruits exhibit hypolipidemic potential in Rattus novergicus. Pharm. Lett. 4: 811-814.

Elekofehinti O.O., Kamdem J.P., Boligon A.A., Athayde M.L., Lopes S.R., Waczuk E.P., Kade I.J., Adanlawo I.G., Teixeira Rocha J.B. 2013. African eggplant (Solanum anguivi Lam) fruits with bioactive polyphenolic compounds exert in vitro antioxidant properties and inhibit $\mathrm{Ca}^{2+}$ induced mitochondrial swelling. Asian Pacif. J. Tropic. Biomed. 3: 757-766.

Elekofehinti O.O., Kamdem J.P., Kade I.G., Rocha J.B.T., Adanlawo I.G. 2013. Hypoglycemic, antiperoxidative and antihyperlipidemic effects of saponins from Solanum anguivi Lam fruits in alloxan-induced diabetic rats. South Afr. J. Bot. 88: 56-61.

Faraz M., Mohammad K., Naysaneh G., Hamid R.V. 2003. Phytochemical screening of some species of Iranian plants. Iran. J. Pharm. Res. 2: 77-82.

Filho V.M.B., Waczuk E.P., Kamdem J.P., Abolaji A.O., Lacerda S.R., da Costa J. C.M., Menezes I.R.A., Boligong A.A., Athayde M.L., Teixeira da Rocha J.B., Posser et T. 2014. Phytochemical constituents, antioxidant activity, cytotoxicity and osmotic fragility effects of Caju (Anacardium microcarpum). Industr. Crops Prod. 55: 280-288.

Halliwell B. 1991. Reactive oxygen species in living systems: Source, biochemistry, and role in human disease. Am. J. Med. 91: 14-22.

Halliwell B., Gutteridge J.M., Cross C.E. 1992. Free radicals, antioxidants and human disease: where are we now? J. Labor. Clin. Med. 119: 598-620.

Harbourne J.B. 1998. Phytochemical Methods: A Guide to Modern Technique of Plant Analysis. $3^{\text {rd }}$ Ed. Chapman and Hall, London \& New York.

Huong N.T., Matsumoto K., Kasai R., Yamasaki K., Watanabe H. 1998. In-vitro antioxidant activity of Vietnamese Ginseng saponin and its components. Biol. Pharm. Bull. 21: 978-81.

Iwu M.M., Duncan A.R., Okunji C.O. 1999. New antimicrobials of plant origin. In: Janick J. (ed) Perspectives in New Crops and New Uses. ASHS Press, Alexandria, pp. 457-462.

Kamdem J.P., Waczuk E.P., Kade I.J., Wagner C., Boligon A.A., Athayde M.L., Souza D.O., Teixeira Rocha J.B. 2012. Catuaba (Trichilia catigua) prevents against oxidative damage induced by in vitro ischemia-reperfusion in rat hippocampal slices. Neurochem. Res. 37: 2826-2835.

Kanatt S.R., Chandler R., Sharma A. 2007. Antioxidant potential of mint (Mentha spicata L.) in radiation-processed lamb meat.
Food Chem. 100: 451-458.

Keser S., Celik S., Turkoglu S., Yilmaz O., Turkoğlu I. 2012. Hydrogen peroxide radical scavenging and total antioxidant activity of hawthorn. Chem. J. 2: 9-12.

Kumar A., Ilavarasan R.I., Jayachandran T., Decaraman M., Aravindhan P., Padmanabhan N., Krishnan M.R.V. 2009. Phytochemical investigation on a tropical plant, Syzygium cumini from Kattuppalayam, Erode District, Tamil Nadu, South India. Pakistan J. Nutr. 8: 83-85.

Malika A.S.B., Mariam F., Mohamed M., Lahcen H., Mustapha L. 2015. Synergistic antimicrobial and antioxidant activity of saponins-rich extracts from Paronychia argentea and Spergularia marginata. Eur. J. Med. Plants 7: 193-204.

Motalleb G., Hanachi P., Kua S.H., Fauziah O., Asmah R. 2005. Evaluation of phenolic content and total antioxidant activity in Berberis vulgaris fruit extract. J. Biol. Sci. 5: 648-653.

Muleya E. 2013. Evaluation of biological activities of nine antiinflammatory medicinal plants and characterization of antimicrobial compounds from Pomaria sandersonii and Alepidea amatymbica. PhD Dissertation, University of Pretoria.

Odebiyi O.O., Sofowora E.A. 1979. Antimicrobial alkaloids from Nigerian chewing stick (Fagara zanthoxyloides). Planta Med. 36: 204-207.

Oktay M., Gülçin I., Küfrevioglu O.I. 2003. Determination of in vitro antioxidant activity of fennel (Foeniculum vulgare) seed extracts. Food Sci. Technol. 36: 263-271.

Olatunji O.A. 1983. The biology of Zanthoxylum Linn (Rutaceae) in Nigeria. In: Anti-infective Agents of Higher Plants Origin. Proceedings of the $5^{\text {th }}$ International Symposium on Medical Plants. Pp. 56-59.

Oyaizu M. 1986. Studies on products of browning reactions: antioxidative activities of 581 products of browning reaction prepared from glucosamine. Jap. J. Nutr. 44: 307-315.

Ruch R.J., Cheng S.J., Klaunig J.E. 1989. Prevention of cytotoxicity and inhibition of intracellular communication by antioxidant catechins isolated from Chinese green tea. Carcinogenesis 10: 1003-1008.

Ryu C.S., Kim C.H., Lee S.Y., Lee K.S., Choung K.J., Song G.Y., Kim B.-H., Ryu S.Y., Lee H.S., Kim S.K. 2012. Evaluation of the total oxidant scavenging capacity of saponins isolated from Platycodon grandiflorum. Food Chem. 132: 333-337.

Sofowora A. 1984. Medicinal Plants And Traditional Medicines in Africa. John Wiley and Sons, Somerset.

Sofowora E.A. 1993. Medicinal Plants and Traditional Medicine in Africa. Spectrum Books, Ibadan.

Sofowora E.A., Isaac-Sodeye W.A., Ogunkoya L.O. 1975. Isolation and characterization of an antisickling agent from Fagara zanthoxyloides root. Lloydi 38: 169-174.

Stintzing F.C., Stintzing A.S., Carle R., Frei B., Wrolstad R.E. 2002. Color and antioxidant properties of cyanidin-based anthocyanin pigments. J. Agric. Food Chem. 50: 6172-6181.

Tan J.B., Lim Y.Y. 2015. Critical analysis of current methods for assessing the in vitro antioxidant and antibacterial activity of plant extracts. Food Chem. 172: 814-822.

Trease G.E., Evans M.D. 1989. A Text Book of Pharmacognosy. $13^{\text {th }}$ Ed. Baillier, Tindal and Caussel, London.

Tsuchiya H., Sato M., Miyazaki T., Fujiwara S., Tanigaki S., Ohyama M., Tanaka T., Iinuma M. 1996. Comparative study on the antibacterial activity of phytochemical flavones against methicillin-resistant Staphylococcus aureus. J. Ethnopharm. 50: 27-34. 
Tsuzuki J.K., Svidzinski T.I., Shinobu C.S., Silva L. A., RodriguesFilho E., Cortez D.A., Ferreira I.C.P. 2007. Antifungal activity of the extracts and saponins from Sapindus saponaria L. Anais Acad. Brasil. Ciênc. 79: 577-583.

Vinay R.P., Prakash R.P., Sushil S.K. 2010. Antioxidant activity of some selected medicinal plants in western region of India. Adv. Biol. Res. 4: 23-26.

Vogel H.G. (ed) 1997. Drug Discovery and Evaluation: Pharmacological Assays. Springer, Berlin.
Xie Z., Huang J., Xu X., Jin Z. 2008. Antioxidant activity of peptides isolated from alfalfa leaf protein hydrolysate. Food Chem. 111: 370-376.

Yildirim A., Mavi A., Oktay M., Kara A.A., Algur O.F., Bilaloglu V. 2000. Comparison of antioxidant and antimicrobial activities of tilia (Tilia argenta Deaf Ex DC), sage (Salvia triloba L.) and black tea (Camellia sinensis) extracts. J. Agric. Food Chem. 48: 5030-5034. 